\title{
DEVELOPMENT OF RELOCATION STRATEGIES REGARDING ERUPTION HAZARD IN MOUNT MERAPI
}

\author{
Rosdiana Puji Lestari \\ Public Works and Housing, Energy and Mineral Resources Office of Yogyakarta Province, Yogyakarta, Indonesia \\ mahmud_ana@yahoo.co.id
}

\begin{abstract}
The aim of this study was to answer these matters: 1) the way government manages the relocation based on current strategy 2) the problems occur due to relocation, 3) the best concept of relocation to minimize those problems. The research methodology used in this study combined quantitative and qualitative methods. Qualitative methods are used to explain the empirical facts that exist in each of real conditions in the relocation settlements. SWOT analysis was used to provide an overview of the strengths, weaknesses, opportunities and threats in the relocation of Merapi disaster victims. Information, facts and issues that arise in the study will be described, explained and analyzed primarily for the impact of residential relocation on social and economic life of the community. The economic aspects of community empowerment efforts should be to recover communities' economy after a change in livelihood. In addition, the potential of community mapping needs to be done by the government to be optimized and developed. From the aspect of government settlements seek to transfer ownership of land in the new settlement which may be the property of the citizens so that citizens obtain legal certainty while occupying the new settlement. The social aspects of the development potential of relocating residents and making it as a tourist village, residents need to support that relocation is no longer a new comer. They have the same rights and obligations with citizens of another.
\end{abstract}

Keywords: Merapi eruption, relocation, economy, social.

\section{INTRODUCTION}

Mount Merapi is located in the between of Province of Central Java and the Special Province of Yogyakarta. Mount Merapi erupts periodically with various magnitude scales. The largest eruption was in 1984 which almost destroyed all of the surrounding ecosystems. Following that disaster, local government determined some parts of the area as the volcanic hazardous areas which one of them was Turgo village. Thus, it was necessary to relocate all of the activities in a safer area. However, because many people neglected the Government's appeal, the 1994 eruption took a lot of lives.

Prior to such hazardous consequences of the 1994 eruption, the government were succeeded in persuading people to be relocated. However, the relocated people are still having problems due to relocation policy.

In a way, resettlement is quite simple. However, relocation was not followed by sustainable countermeasures. This was indicated by problems arouse such as relocation implementation problem, community problem and other complicated problems. Various social, economic, and cultural approaches are taken as the success milestones in relocating the residents to a safer area. The social-economy insurance for the relocated residents becomes an essential aspect, so that the people as well as the structure and the system will not be harmed. The loss of the living hood and income source might generate ecosystem exploitation, life difficulties, social stress and poverty (Mathur, 2011).

The objective of this study is to analyze the following problems: 1) the relocation strategies taken by the government by using the case study of the relocation of the people in Sudimoro Village, Purwobinangun, Pakem, Sleman, Yogyakarta, prior to Merapi eruption in $1944 ; 2$ ) the problems to be solved due to relocation, 3) the proper concept of relocation to minimize the problems.

\section{RELOCATION CONCEPT}

\subsection{Natural Disaster Management Cycle}

Natural disaster is one of the factors with potential to change the surrounding social living. Social living is inseparable from nature influence. When a natural disaster happens, it also gives impacts to the social living such as destruction of the natural environment and the surrounding social living.

Law of The Republic of Indonesia Number 24, 2007 defines natural disaster as an occurrence or a series of occurrences which threaten and disturb the living and the society subsistence and caused by natural factor 
and/or non-natural or human factors that cause many victims including human lives, environment disturbance, material loss, and psychological impacts. Furthermore, natural disaster is caused by natural factors such as earthquake, tsunami, volcanic eruption, flood, draught, typhoon, and landslide. The disaster management is established in a cycle as mentioned in Law of The Republic of Indonesia Number 24, 2007. It starts with emergency countermeasures, rehabilitation, prevention and mitigation, awareness as shown in Figure 1.

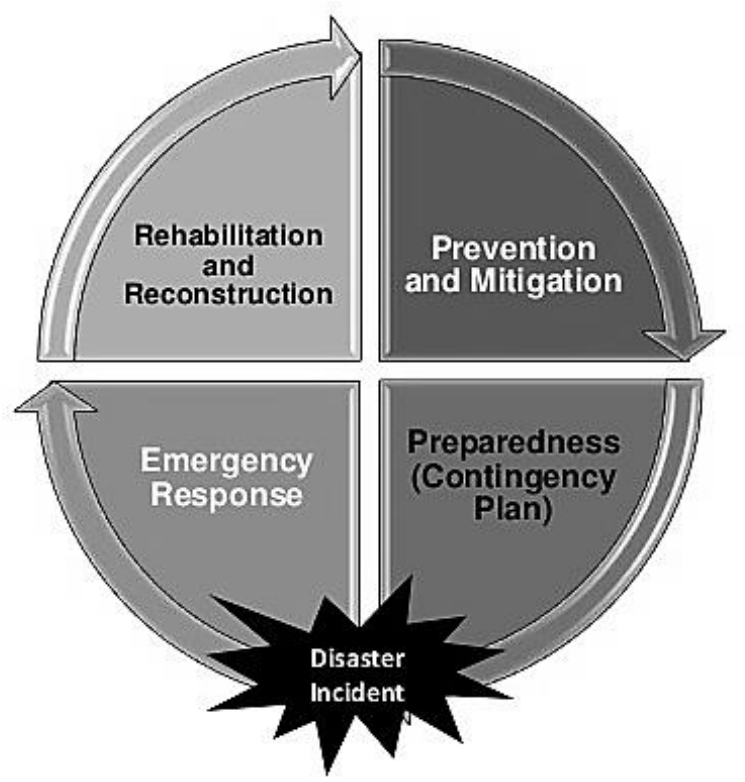

Figure 1. Disaster Management Cycle (Sulistioningrum, 2013)

\subsection{Relocation of Disaster Victim}

According to Farida (2010), the success of a relocation settlement activity is not only about removing communities affected with natural disaster to a new settlement. Instead, it also concerns about how the social, economic and settlement conditions after the relocation. Relocation in an urban area often results in physical and economic displacement affecting the settlement, employment and companies. The main challenge associated with relocation involves the changing of livelihood which is closely related to the location condition such as proximity to the workplace, customers and markets.

Previous studies on resettlement showed unfavorable results. Handrianto (1996) examined the process of relocation of people from slum areas. The failure of the identified population transfer is the inadequacy community involvement in the government policies function. Relocation or resettlement programs are the government objectives which are composed in a top down approach, resulting in a misalignment between the vision and mission to the needs and aspiration of the people.

Arif (2003) observed that when it is not followed by superstructure and infrastructure readiness, the process of resettlement or relocation can only be an effort that hampers the development. Relocation generates new problems that displacement of people tends to worsen the existing problems. On the other hand, forcible relocation will only result in uneasiness. Once the people are attacked and displaced, they will move again and raid another location (Budiharjo, 1994).

Various cases of relocation indicate that failure of a relocation task should still be included in the development agenda. Instead of only a matter of the layout, it also relates to the public welfare. Furthermore, it is required to put efforts of development of the relocation model, especially in disaster-prone areas of the top down situation and without involving the people into the normal situation. Therefore, it is also necessary to study and comprehend the good and bad practices through the approach of socio-economy and cultural changes of the people in the relocation area.

\section{RESEARCH METHOD}

This study is a descriptive research and applied the problem approach. Information, facts, and issues were to be described, explained, and analyzed especially regarding the effects of the relocation to the social economic condition of the people.

The command area was located in Sudimoro village, Purwobinangun sub-district, in Sleman regency. Analysis approach used the questioners and interviews given to the 1994 Merapi eruption victims, to obtain the most updated data, condition, and problems valuable for the analysis.

The research method applied in this research combined the quantitative and qualitative method. Qualitative method was used to explain empirical facts of each of the settlement condition in the relocation place. Conditions between before and after relocation were then compared. The changes of condition were explained by using the descriptive method that included the influencing factors of the change. SWOT analysis was used to provide description of the strength, weakness, opportunity, and threat of the relocation of Merapi victims. 


\section{RESEARCH RESULT AND DISCUSSION}

\subsection{Relocation Strategy}

Relocation strategy prior to the 1994 eruption was appeared to be improperly constructed. This can be indicated by the remaining existence of the problem up to 2012. This problem was caused by a fundamental consideration that the most important thing to do at that time was evacuating the people from the dangerous location. The eruption also caused trauma to people so they fear to stay on their origin anymore.

On the other hand, the government is in dilemma for they are hindered by the law about transferring village-possession land to be used as the relocation area. The relocated people are now living in villageauthority possession land with no possibility for them to have the ownership rights.

\subsection{Problems Prior to Relocation}

After the relocation, there are some problems occurred which included the problems of land ownership, settlements, socio-culture, and also economy.

\subsubsection{Land Ownership}

Some problems relating to land ownership included the proprietary status, expensive cost of land rent and insufficient information received by the people. The people resumed the problems as the following.

"The government has promised us that we, the relocated people, could dwell this land through generations. However, in fact, until now, the status of this land has not been clarified" (Marwoto, 2011).

"We complain about the rent of the land, which is quite expensive, so it causes confusion to the people; "We want to rent but cannot afford it. But if not, we do not know anywhere else to rent" (Ahmad, 2011).

"We are afraid that one day, our grandchildren who live here will be expelled just like what had happened to the people who lived in council house because we have no legal certificate of this house and this land" (Pujo, 2011).

\subsubsection{Settlements}

Law no 41992 mentions that settlements and residences are essentials for human living. It has strategic role in forming character and personality of the nation and requires to be developed for the sake of the people's viability. For that reason, we cannot view settlements and residences as mere facilities, but they are also the dwelling process of human to create space for socializing themselves and appearing their selfidentity. The condition of the settlement in the relocation area is apparently not suitable with even to a simple and healthy settlement as required by the law. There are some items unsuitable with government regulation, such as land and building status, and the division of the room in the house. In this case of relocated people, both land and building statuses have significant influence to their life although they have been living in relocation area for 17 years.

\subsubsection{Social and Culture}

Most of the people feel degrading activities in the relocation area. At their previous village, they often do village cleaning together, even almost every day. However, after the relocation, they do it incidentally or in some special occasion only, such as the welcoming of the Independence Day or when there is guest visit.

However, education, health, economic and new housing facilities are better than the previous village. The health is also improved compared to before relocation. This is due to the cleaner environment and the easier access to local health clinic (less than 1 $\mathrm{km})$. Social problem such as resistance of the original people of the relocation area was denied by the head of the village.

Such assumption happened because some relocated people miss to attend the routine meeting held by the village. Thus, they have no representative to express their opinion on that meeting. The following statement was from local village authority.

"The feeling of being uncared relocated residents has been a special report. This is due to their self-attitude of not being active in the meetings/consultations held every Friday Kliwon. If they actively attend the meeting, they will not feel being ignored" (Village Head, 2011).

This problem was caused by poor communication between people and village authority. Government role is required to encourage the relocated people to attend the routine meetings as explained by the head of the village.

\subsubsection{Economics}

Based on the people economic condition, relocation influences the assets ownership on land status, that the people are not the owner anymore. Before the relocation, they lived in their own house and land. After being relocated, they have to pay Rp100,000.00 
every year to rent the land. This, of course, burdens them because they have not prepared such amount of money, in addition that they do not have clear status on the ownership of land and building. They are potentially expelled any time, although the government has given the promise that they and their next generation can dwell the land and the building.

The people also feel economics changes in fulfilling their daily needs. At their previous village, their needs of vegetables and rice could be fulfilled by their work because most of them were farmers who had land and planted vegetables in their own home yards. It was also the same with their need for clean water. At their previous place, they obtained clean water directly from spring which had good quality and much quantity. However, at their new place, the water is fulfilled only from wells in every house or from Municipal Water Corporation.

Actually, any employment opportunity can be found in the relocation area. Some of them are microeconomic and household works. Unfortunately, not many people are aware with such opportunity. As a result, they complain about their poor economic condition after living in relocation area. Apparently, their only economic activity capability is farming especially cattle. In the new place, there is not enough land for grazing the cattle. For those with better employments, such as government civil servants, relocation has no significant effect to their economic condition.

Based on the data and the empirical condition, SWOT analysis was used to set the proper strategy of good relocation concept. This analysis was begun with mapping the opportunity, strength, weakness, and threat. The mapping result is presented on the Table 1 and Table 2.

Priority level of relocated people can be formulated based on the identification of opportunity, weakness, strength and threat.

Table 1. Calculation of priority strategy target level

\begin{tabular}{|c|c|c|c|c|c|}
\hline No & Strategy Factors & Score & Rating & Total & Priority \\
\hline \multirow[t]{3}{*}{1} & Strategy S-O & & & & \\
\hline & $\begin{array}{l}\text { 1. Establishment of cooperative or joint venture entities (managed by the relocated } \\
\text { people) }\end{array}$ & 0.75 & 4 & 3.00 & II \\
\hline & 2. Empowerment of communities in the management of communal livestock & 0.75 & 4 & 3.00 & II \\
\hline \multirow[t]{3}{*}{2} & Strategy W-O & & & & \\
\hline & 1. Conducting the training and mentoring programs for the relocated people & 0.75 & 4 & 3.00 & II \\
\hline & 2. Providing economic aid recovery & 1.00 & 3 & 3.00 & II \\
\hline \multirow[t]{5}{*}{3} & Strategy S-T & & & & \\
\hline & 1. Forming a coordinating team with the government regarding the land status & 1.00 & 4 & 4.00 & I \\
\hline & 2. providing assurance of the land legal ownership in the relocation area & 1.00 & 4 & 4.00 & I \\
\hline & 3. providing regulations to prohibit settlements in disaster-prone locations & 0.50 & 4 & 2.00 & IV \\
\hline & 4. Building law enforcement for the social system disaster area & 0.50 & 4 & 2.00 & IV \\
\hline \multirow[t]{4}{*}{4} & Strategy T-W & & & & \\
\hline & 1. Conducting discussions and integration with the surrounding community & 0.67 & 3 & 2.01 & III \\
\hline & 2. Developing rural tourism potential & 1.00 & 2 & 2.00 & $\mathrm{~V}$ \\
\hline & 3. Providing compensation for relocated people & 0.67 & 4 & 2.68 & II \\
\hline
\end{tabular}

Table 2.SWOT analysis mapping

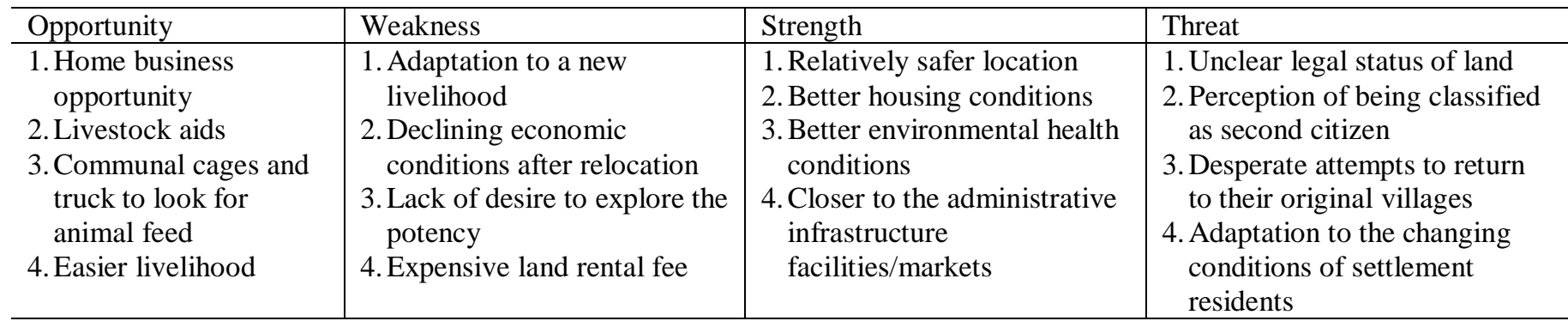




\section{CONCLUSIONS AND RECOMMENDATIONS}

\subsection{Conclusions}

The following statements are the relocation concepts obtained from this research.

a) Economics

Society empowerment should be taken concerning the economic recovery after the changing of livelihood. This was started by giving stimulus fund and supervision to generate people in fulfilling their economic needs by themselves. Besides, it is also required for the government to map the social potency for optimizing and developing the people.

\section{b) Settlements}

Government has to put some efforts to transfer the land ownership of new settlement in order to give the people legal certainty while occupying the new settlement and to prevent them to re-build their previous homes in disaster-prone areas. The most fundamental point is the certain status of the land in the relocation area. Next, it would be the infrastructure conditions in relocation area. It is also required to analyze the availability of land and infrastructure in the relocation area.

c) Socials

Assistance is required in the form of training, especially related to changes of their livelihoods, for example, changing farmers and ranchers into construction worker, which requires builder or construction worker trainers. Potency for the development of tourist village may support a sense of civic pride for the people that their presence in the relocation sites will contribute to the community and to make them feel not being newcomers anymore who have the same rights and obligations with the people who are originally live in the relocation area before they came.

\subsection{Recommendations}

Based on the abovementioned results of the analysis, the following recommendations can be drawn:

a) It is recommended for the government to have clear and comprehensive relocation policy with no possibility of leaving problems for the citizens, especially in the aspect of legal ownership of the land, social, cultural, and economic activities as well as local knowledge.

b) Urgent measures that can be used as input in the implementation of the relocation in this case, such as forming a coordinating team with the government related to the land ownership status, providing assurance of legal ownership of the land at the relocation sites, providing compensation by the government for people who are willing to be relocated and committed of not going back to their previous villages, providing economic recovery aid coupled with mentoring and training, establishing cooperative or joint venture entities (managed by the relocated people), and developing the potency of rural tourism.

\section{REFERENCES}

Arif, A., 2003. Alternatif Desain Hunian untuk Tepian Sungai [Design Alternative of Settlement in

Riverside\}. Kompas, 30 March, p. 15.

Budiharjo, E., 1994. Percikan Masalah Arsitektur, Perumahan, Perkotaan [Fragment of Architecture, Settlement, and Urban Problem]. Yogyakarta: Gadjah Mada University Press.

Farida, E., 2010. Konsep Relokasi Permukiman Bencana Alam Banjir (Studi Kasus Kabupaten Situbondo Jawa Timur) [Concept on Relocation of Settlement after Flood Hazard (Case Study on Situbondo Regency, East Java)].

Handrianto, 1996. Jurnal Pembangunan Wilayah dan Kota [Journal of Urban and Spatial Development], Volume 22.

Mathur, M., 2011. Social Impact Assessment : A Tool for Planning Better Resettlement. Social Change Journal, 41(1), pp. 97-120.

Sulistioningrum, D., 2013. Using OSM,QGIS and INASAVE for Contigency Plan, Manila: Atheneo De Manila University. 
[this page intentionally left blank] 